\title{
$\mathrm{CABYV}$ 감염 멜론의 황화증상에 따른 생리적인 특성
}

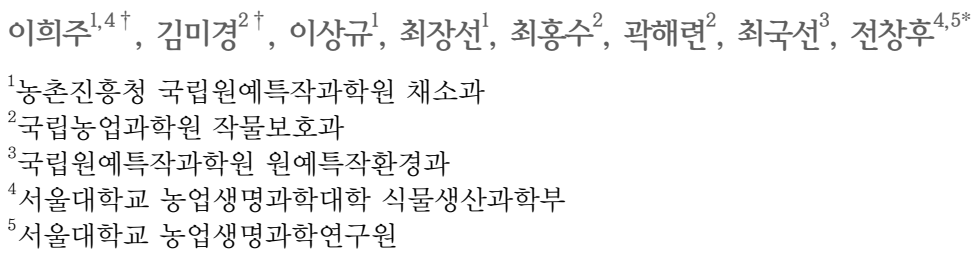

\section{Physiological Characteristics of Melon Plants Showing Leaf Yellowing Symptoms Caused by CABYV Infection}

\author{
Hee Ju Lee ${ }^{1,4 \dagger}$, Mi-Kyeong Kim ${ }^{2 \dagger}$, Sang Gyu Lee ${ }^{1}$, Chang Sun $\mathrm{Choi}^{1}$, Hong-Soo $\mathrm{Choi}^{2}$, Hae Ryun Kwak ${ }^{2}$, Gug Seoun Choi ${ }^{3}$, and \\ Changhoo Chun ${ }^{4 *}$ \\ ${ }^{1}$ Vegetable Research Division, National Institute of Horticultural and Herbal Science, Wanju 565-852, Korea \\ ${ }^{2}$ Crop Protection Division, National Academy of Agricultural Science, Wanju 565-852, Korea \\ ${ }^{3}$ Horticultural \& Herbal Crop Environment Division, National Institute of Horticultural and Herbal Science (NIHHS), Rural Development Administration \\ (RDA), Wanju 565-852, Korea \\ ${ }^{4}$ Department of Plant Science, College of Agriculture and Life Sciences, Seoul National University, Seoul 151-921, Korea \\ ${ }^{5}$ Research Institute of Agriculture and Life Sciences, Seoul National University, Seoul 151-921, Korea
}

\begin{abstract}
Melon leaves showing yellowing symptoms were analyzed using electron microscopy and RT-PCR for major cucurbitinfecting-viruses (CMV, MNSV, CGMMV, SqMV, WMV, KGMMV, PRSV and ZYMV) reported in Korea, but these viruses were not detected. As the result of further analysis by next-generation sequencing (NGS), the virus was identified as Cucurbit aphid-borne yellows virus (CABYV), and then confirmed by RT-PCR using CABYV-specific primers. When photosynthetic capacity was measured based on chlorophyll fluorescence yield (ChlFY), the leaves of the diseased plants showed $4.09 \mu \mathrm{mol} \cdot \mathrm{m}^{-2} \cdot \mathrm{s}^{-1}$, which was one-third of the readings observed for unaffected normal plants $\left(12.36 \mu \mathrm{mol} \cdot \mathrm{m}^{-2} \cdot \mathrm{s}^{-1}\right)$. The root functions of plants affected by leaf yellowing symptoms (LYS) was $0.28 \mathrm{mg} \cdot \mathrm{g}^{-1}$, about half that measured for the normal unaffected plants $\left(0.48 \mathrm{mg} \cdot \mathrm{g}^{-1}\right)$. Cytological observations revealed that there were no morphological differences in the palisade parenchyma and mesophyll spongy cells of the leaves between the diseased and the normal plants. However, the same leaf cells of the affected plants contained more starch granules compared to those of the normal, unaffected plants. We conclude that the LYS of muskmelon is not merely a physiological disorder but a viral disease caused by CABYV and spread by aphids.
\end{abstract}

Additional key words: aphids, leaf yellows, melon disease, virus disease

\section{서 언}

최근 들어 멜론의 맛과 가격이 적정 수준으로 유지되면서 국내 소비량이 증가하고 있으며, 일부 지역에서는 해외로
수출까지 하고 있어 농업인의 큰 소득원으로 자리잡고 있다. 우리나라에서는 멜론이 대부분 시설 내에서 재배되기 때문 에 연중 생산이 가능한데 특히 6-9월까지 생산되는 여름작 형에 가장 많이 재배되고 있다. 그런데 멜론 시설재배지에

\footnotetext{
*Comesponding author: changhoo@snu.ac.kr

${ }^{\dagger}$ These authors contributed equally to this work.

※ Received 4 September 2014; Revised 22 December 2014; Accepted 6 January 2015.

(C) 2015 Korean Society for Horticultural Science
} 
서는 몇 년 전부터 잎이 황화되는 증상이 발생하기 시작하 였는데, 그 발생 지역과 면적이 점차 확대되면서 멜론 안정 생산에 문제가 되고 있다(Park et al., 2011). 황화엽 증상은 정상엽에 비해서 잎이 황화증상을 보이고, 처음에는 하위엽 에서 시작하여 점점 상위엽으로 진행된다. 황화엽이 발생되 면 생육이 더디고, 과실 비대가 느려지며 네트 형성이 되지 않고, 당도가 낮아지는 등 상품과 생산이 어렵다(Park et al., 2011). 이러한 멜론의 황화엽 증상은 재배상 환경조건에 의 해 발생되는 생리적인 원인과 바이러스 이병에 의해 나타나 는 것으로 추정되지만(Park et al., 2011; Takeshita, 2004) 정 확한 원인은 아직 밝혀지지 않았다. 진딧물 매개에 의한 바 이러스 감염으로 발생하는 황화증상은 생리적인 원인에 의 해 발생할 수 있는 황화증상과 유사하지만 멜론에 있어서는 서로 다른 원인에 의한 것으로 추정되고 있으며, 생리적인 원인에 의한 것은 뿌리 양이 적거나 잎이 크고 넓은 품종으 로 과실비대가 잘되는 품종에서 많이 나타난다고 보고되었 다(Takeshita, 2004). 멜론은 과실 성숙기에 서서히 시들다가 갑작스럽게 황화가 진전되면서 품질 저하를 초래하여 경제 적 손실을 입힌다고 하였으며(Lee et al., 2009), 오이에서는 근권온도가 $15^{\circ} \mathrm{C}$ 에서 황화증상이 일어나며 잎이 어리고 저 온에 노출되는 시간이 길어질수록 황화증상이 더욱 급속하 게 진전된다고 하였다(Moon, 2001).

전 세계적으로 박과작물에서 발생되는 바이러스는 Cucumber mosaic virus(CMV; Enzie, 1943), Watermelon mosaic virus (WMV; Diaz-Pendon et al., 2005), Cucumber green mottle mosaic virus(CGMMV; Rajamony et al., 1987), Melon necrotic spot virus(MNSV; Choi et al., 2003; Kim et al., 2008; Kim et al., 2012), Squash mosaic virus(SqMV; Avgelis and Katis, 1989), Papaya ringspot virus(PRSV; Bateson et al., 1994; Grafton-Cardwell et al., 1996) Zucchini yellow mosaic virus (ZYMV; Dukic et al., 2002; Papayiannis et al., 2005; Vucurovic et al., 2009), Kyuri green mottle mosaic virus(KGMMV; Choi, 2001; Tan et al., 2000), Cucurbit aphid-borne yellows virus(CABYV; Guilley et al., 1994) 등 39종 이상의 바이러 스에 감염되는 것으로 알려져 있다(Lecoq et al., 2003). 그 중에서도 CABYV는 프랑스에서 1992년에 처음 발생이 보 고되었고(Lecoq, 1999), CABYV 감염 멜론의 경우 $40 \%$ 정 도의 상품 수량이 감소한다고 보고된 바 있지만(Lecoq, 1999; Lecoq et al., 2012) 아직까지 국내에서 발생되었다는 보고 (Ryu, 2009)는 없다. 따라서 본 실험은 우리나라 멜론재배지 에서 발생되고 있는 황화엽 증상의 발생 원인과 황화엽 발
생이 근활력 및 광합성에 미치는 영향을 다양한 각도에서 구명하고자 수행되었다.

\section{재료 및 방법}

경북 구미, 전북 남원 및 충남 청양지역에서 황화증상을 보이는 멜론 식물체를 채집하고 국내에 보고되어 있는 박과 감염 바이러스 8종(Table 1)에 대하여 전자현미경과 RT-PCR 검정을 수행하였다. 또한 국내 미보고된 새로운 바이러스 의 진단을 위해 차세대유전체염기서열분석(Next generation sequencing, NGS)을 이용하여 바이러스 감염여부를 진단하 였다. NGS 및 Bioinformatics 분석은 (주) C\&K Genomics (Seoul, Korea)에 의뢰하여 수행하였다. NGS는 Illumina사 의 프로토콜에 따라 Hiseq2000을 이용하여 Read length $101 \mathrm{bp}$ paired-end로 수행되었으며 약 $16.8 \mathrm{Gbp}$ 의 데이터를 생산하였다. 생산된 NGS데이터의 분석을 위해 NCBI에 있 는 식물 바이러스의 sequence $\mathrm{DB}$ 를 구축하였고 이 Database 에 Short read aligner인 Bowtie2(Langmead and Salzberg, 2012)를 이용하여 생산된 NGS 데이터를 Align하였다. Read mapping Coverage $>90 \%$, average mapping depth $>10 \times$ 를 만족하는 reference virus sequence 중 가장 높은 mapping coverage와 depth를 보이는 시퀀스를 후보 바이러스로 선발 하였다. 이렇게 선발된 virus sequence와 NGS 데이터를 이용 하여 genome re-sequencing을 수행하였으며(Carver et al., 2010; Li et al., 2009; McKenna et al., 2010), 변이를 발굴하 고 이 변이와 reference virus sequence를 이용하여 샘플 내 에 포함되어 있는 virus 유전체의 염기서열을 재구성하였다. 재구성된 virus sequence는 계통 유연관계 확인을 위하여 기 존에 알려진 같은 종류의 virus complete sequence와 함께 phylogenetic 분석에 사용되었다. Phylogenetic tree는 Mega 6.0(Tamura et al., 2013)을 이용하여 수행되었으며 muscle sequence alignment, neighbor Joining method with bootstrap $1,000 \times$, maximum composite likelihood 기반의 consensus tree로 분석되었다. Bioinformatics 분석을 통해 진단된 바이 러스의 RT-PCR 진단법 확립을 위해서 CABYV 특이 프라 이머를 선발하였다(Fig. 1). RT-PCR은 total RNA $1 \mu \mathrm{L}$ 을 사 용하여 $10 \mu \mathrm{mol}$ 농도의 정방향과 역방향 primer를 각각 $0.5 \mu \mathrm{L}$, DW $7 \mu \mathrm{L}$ 와 2x RT-PCR premix $10 \mu \mathrm{L}$ (Genetbio SR-8000, Korea)를 첨가하여 전체 $20 \mu \mathrm{L}$ 로 반응을 수행하였다. RT-PCR 조건은 $50^{\circ} \mathrm{C}, 30$ 분의 역전사 반응과 $95^{\circ} \mathrm{C}, 10$ 분의 변성 후, $95^{\circ} \mathrm{C}$ 에서 30 초, $55^{\circ} \mathrm{C}$ 에서 30 초, $72^{\circ} \mathrm{C}$ 에서 1 분 과정을 35 
회 반복 후, 마지막으로 $72^{\circ} \mathrm{C}$ 에서 5 분간 반응시켰다. $\mathrm{PCR}$ 산물은 $1 \%$ agarose gel에서 60 분간 전기영동 후 ethidium bromide로 염색하여 UV광 하에서 확인하였다.

멜론 황화엽증이 발생된 개체의 잎과 정상개체의 잎을 대
상으로 광합성능력과 뿌리의 활력을 조사하였다. 광합성특 성은 광합성측정기(LI-6400, Portable photosynthesis system, LI-COR Inc., Nebraska, USA)를 사용하여 정상엽과 황화엽 을 2주씩 3 반복으로 조사하였다. 광합성 측정기의 측정 조

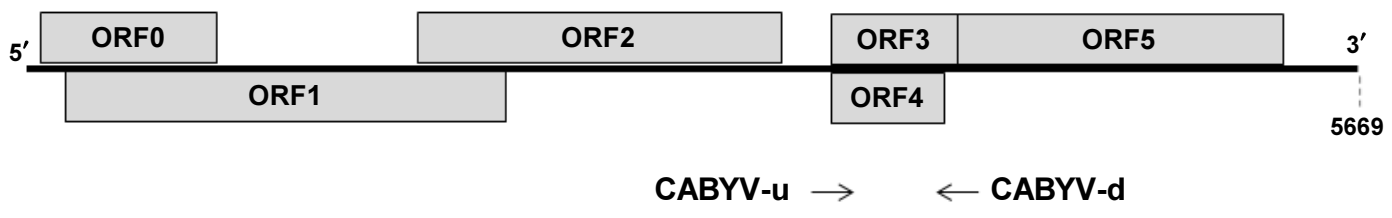

GCTAGAAATCAAAATGCAGGGAGGCG

AGTATTCCAGAGCTGAATGCTGGG

Fig. 1. CABYV specific primer design.
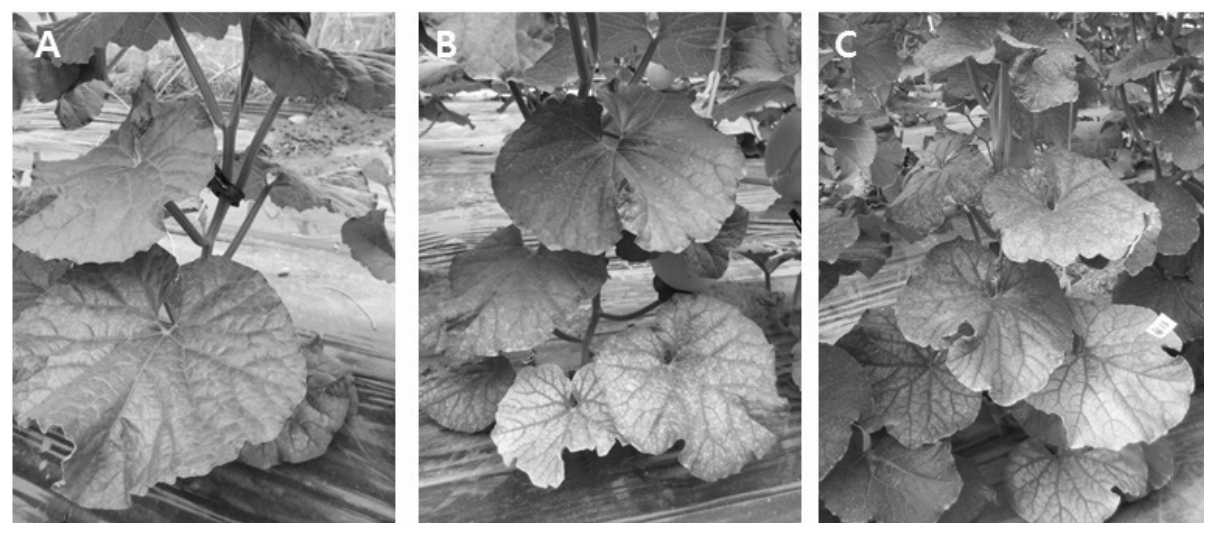

Fig. 2. Typical yellowing symptoms of the musk melon leaves. A, Healthy; B, Mild; C, Severe yellowing symptom.

Table 1. Cucurbit-infecting viruses reported in Korea.

\begin{tabular}{|c|c|c|c|c|c|}
\hline Virus & Genus & Primer name & Primer sequence $\left(5^{\prime} \rightarrow 3^{\prime}\right)$ & Product size & Particle \\
\hline \multirow{2}{*}{ MNSV } & \multirow{2}{*}{ Carmovirus } & MNSVpu5 & TGGAGGTAYATGAATGATAC & \multirow{2}{*}{$535 b p$} & \multirow{2}{*}{ Isometric } \\
\hline & & MNSV pd5 & TAGGCGAGGTARGCRGTTTC & & \\
\hline \multirow{2}{*}{ CGMMV } & \multirow{2}{*}{ Tobamovirus } & CGMM-N30 & ATGGAACGTACCGGAATC & \multirow{2}{*}{$609 \mathrm{bp}$} & \multirow{2}{*}{ Rod-shaped } \\
\hline & & CGMM-C60 & AATTAAGTAAAGTCCTGACG & & \\
\hline \multirow{2}{*}{ SqMV } & \multirow{2}{*}{ Comovirus } & SqMV $1 F$ & TGGAGAGTTTYCCCCACAAG & \multirow{2}{*}{ 491bp } & \multirow{2}{*}{ Isometric } \\
\hline & & SqMV 1R & TTCTTCCAAGCAGCCACTTT & & \\
\hline \multirow{2}{*}{ KGMMV } & \multirow{2}{*}{ Tobamovirus } & KG-N60 & AGTCGCGCATTGCTGCTTTGAT & \multirow{2}{*}{ 403bp } & \multirow{2}{*}{ Rod-shaped } \\
\hline & & KG-C10 & GAGAACTTACAGATAG & & \\
\hline \multirow{2}{*}{ ZYMV } & \multirow{2}{*}{ Potyvirus } & ZYM-C10 & AGGCTTGCAAACGGAGTCTAAT & \multirow{2}{*}{$510 \mathrm{bp}$} & \multirow{2}{*}{ Filamentous } \\
\hline & & ZYM-N50 & TATATAGAGATGAGAAATGCAGA & & \\
\hline \multirow{2}{*}{ WMV2 } & \multirow{2}{*}{ Potyvirus } & WMV-UNI-1F & CAGTTTGAATCATGGTACAGCGC & \multirow{2}{*}{ 392bp } & \multirow{2}{*}{ Filamentous } \\
\hline & & WMV-UNI-1R & TGTGCTATTGCTTCTCTTGCCC & & \\
\hline \multirow{2}{*}{ PRSV } & \multirow{2}{*}{ Potyvirus } & PRS-C10 & AGACTCAGAGAACTCGAAT & \multirow{2}{*}{$610 \mathrm{bp}$} & \multirow{2}{*}{ Filamentous } \\
\hline & & PRS-N60 & CAATTTGAGAAGTGGTATGAG & & \\
\hline \multirow{2}{*}{ CMV } & \multirow{2}{*}{ Cucumovirus } & CMV DP u1 & CGTCGTGGTTCCCGCTCCG & \multirow{2}{*}{ 473bp } & \multirow{2}{*}{ Isometric } \\
\hline & & CMV DP d2 & AGCGCGCATCGCCGAAAGAT & & \\
\hline
\end{tabular}


건은 온도 $25^{\circ} \mathrm{C}$, 상대습도 $60 \%, \mathrm{CO}_{2}$ 농도는 $400 \mathrm{ppm}$, 광량 은 $1,000 \mu \mathrm{mol} \cdot \mathrm{m}^{-2} \cdot \mathrm{s}^{-1}$ 로 하였다. 뿌리의 활력 조사는 Berridge et al.(2005)의 방법으로 하였는데, 발생된 포장 내에서 황화 엽 증상(Fig. 2)을 보인 것과 정상적인 주를 대상으로 2주씩 3 반복으로 조사하였다. 뿌리 채취는 수확 3 주 전에 정식부위 를 중심으로 반경 $50 \mathrm{~cm}$, 깊이 $30 \mathrm{~cm}$ 부위의 뿌리를 채취하여 흐르는 물에 씻은 후 측정에 이용하였다. 뿌리 시료는 세근 을 약 $0.5 \mathrm{~cm}$ 길이로 절단하여 균일하게 혼합한 후 $0.1 \mathrm{~g}$ 을 취하여 test tube에 넣고 $1 \mathrm{~mL}$ 의 증류수와 혼합한 후 Premix WST-1 cell proliferation assay system(Takara Inc., Tokyo, $\mathrm{Japan}$ ) 시약 $10 \mu \mathrm{L}$ 를 가하였다. 이것을 암상태로 $25^{\circ} \mathrm{C}$ 에서 3 시간 동안 반응시킨 후 ELISA reader(Microplate Spectrophotometer, Eon ${ }^{\mathrm{TM}}$, BioTek Inc., Vermont, USA)를 이용하여 흡광도 $420 \mathrm{~nm}$ 로 분석하였다. Premix WST-1 cell proliferation assay system 시약 $10 \mu \mathrm{L}$ 를 증류수에 혼합하여 blank로 이용 하였다. 세포조직 현미경 촬영은 Chang(1973)의 방법으로 하였는데, 채취한 잎을 1 차 고정액 $2.5 \%$ glutaraldehyde에 넣은 즉시 모든 과정은 $4^{\circ} \mathrm{C}$ 에서 진행되었으며 1차 고정 90 분간 처리, $0.1 \mathrm{M}$ phosphate buffer(pH 7.2)로 15 분 간격 4-5 회 세척, 2 차 고정 $1 \%$ osmium tetroxide 90 분간 처리, 위와 동일한 세척 과정 후 하룻밤을 침지시켰다. 탈수는 상온에 서 $40,60,80,90,95 \%$ ethanol로 각각 5 분씩, $100 \%$ ethanol 로 $5,15,15,30$ 분간 처리로 이루어졌으며 propylene oxide 로 치환 후 최종적으로 epon에 포매(embedding)하여 $60^{\circ} \mathrm{C}$ 의 오븐에서 4 일간 중합시켰다. 중합된 epon block을 초미
세절편기(Ultracut R ultramicrotome, Leica Mycrosystems, North Ryde, Australia)를 이용하여 $1,500 \mathrm{~nm}$ 의 두께로 시료 를 절단하여 periodic acid and Schiff's reagent 염색법으로 염색한 후 광학현미경(Axioskop 2, Carl Zeiss, Oberkochen, Germany) 100 배로 검경하였다.

잎의 무기성분은 수액분석을 위해 절단하였던 개체의 잎 을 채취하여 $80^{\circ} \mathrm{C}$ 가 유지되는 건조기에서 3 일간 건조한 후 분말을 만들어서 분석에 사용하였다. 식물체 분석은 토양화 학분석법(NIAST, 2000)의 식물체 분석법에 준하여 원소흡 광분석기(AA-6800, Shimadzu, Kyoto, Japan)를 사용하여 분 석하였다.

통계분석은 SAS 프로그램(SAS 9.2, SAS Institute Inc., $\mathrm{USA}$ )을 이용하여 $\mathrm{t}$ 검정으로 수행한 후 그 결과를 표에 나 타냈다.

\section{결과 및 고찰}

경북 구미지역에서 채취된 황화증상을 보이는 멜론에 대 하여 전자현미경 검경 및 국내 보고(Ryu, 2009)된 박과 감 염 바이러스 8종(CMV, MNSV, CGMMV, SqMV, WMV, $\mathrm{KGMMV}, \mathrm{PRSV}, \mathrm{ZYMV}$ )에 대해 RT-PCR한 결과, 바이러 스가 진단되지 않았다(data not shown). 이에 국내에 보고되 지 않은 새로운 바이러스로 의심되어 차세대유전체염기서 열분석(NGS)을 이용하여 진단한 결과, 박과진딧물매개바이 러스(CABYV)로 판정되었고, 전체 contig sequence를 계통
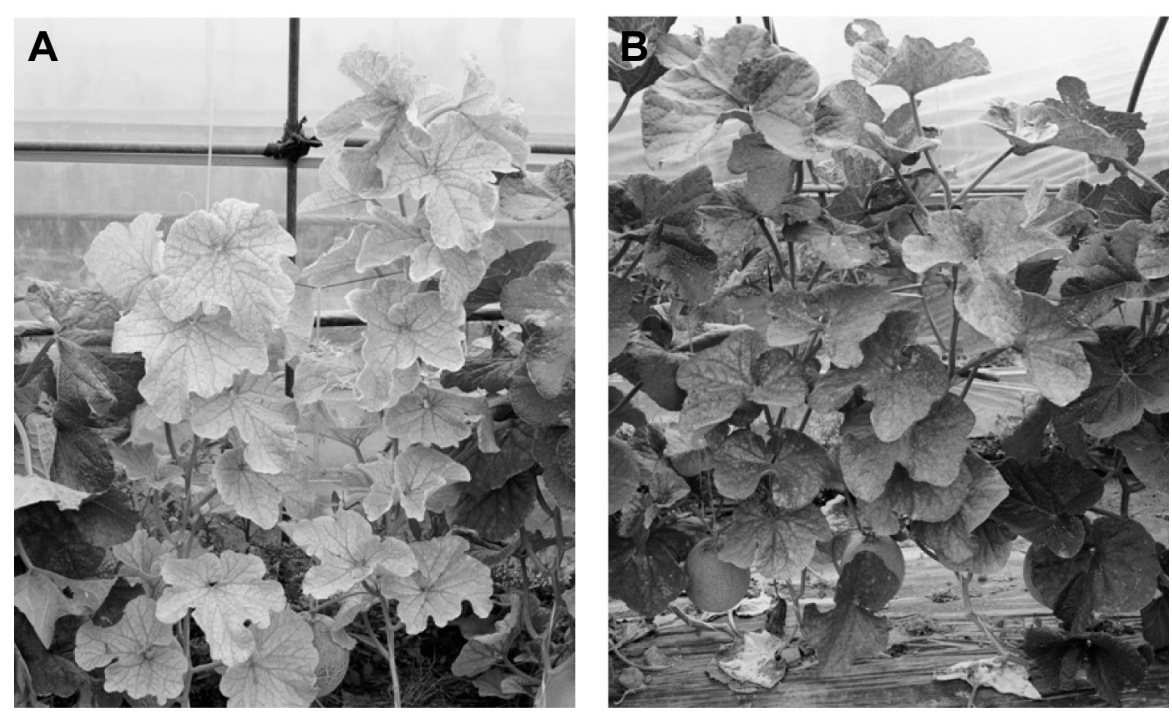

Fig. 3. Symptoms in melons infected with Cucurbit aphid-borne yellows virus. A, Infection on 20 days after transplanting; B, Infection on 60 days after transplanting. 
분석한 결과 $\mathrm{CABYV}$ 일본에서 보고된 바이러스와 상동성 이 높은 것으로 확인되었다(Table 2).

$\mathrm{CABYV}$ 진단 프라이머 중 CABYV 특이 프라이머를 선 발하여 황화증상(Fig. 3)을 보이는 구미에서 채취한 멜론 21 점을 검정한 결과, 20 점이 $\mathrm{CABYV}$ 에 감염된 것을 확인할 수 있었고, 나머지 1점은 다른 요인에 의해서 황화증상을 보인 것으로 판단된다(Fig. 4). 또한 전북 남원과 충남 청양
지역으로부터 황화 증상을 보이는 시료 각각 8점을 $\mathrm{CABYV}$ 특이 프라이머를 이용하여 RT-PCR한 결과, 모두 CABYV 감염이 확인되었다(Fig. 5).

CABYV는 Luteoviridae과 Polerovirus속에 속하는 직경 $23 \mathrm{~nm}$ 의 구형바이러스로 진딧물에 의해서 영속전염(순환형) 되는 것으로 알려져 있으며, 프랑스(Lecoq, 1999)에서 처음 보고된 이후 이탈리아(Tomassoli and Meneghini, 2007), 스페

Table 2. List of candidate complete genome sequencing of melon sample.

\begin{tabular}{|c|c|}
\hline ID & Description \\
\hline gi|113460144|ref|NC_008310.1| & "Hibiscuslatent Singaporvirus, completegenome" \\
\hline 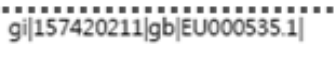 & "'Cucurbitaphid-boyellows virus, completegenome" \\
\hline gi|194320363|gb|EU636992.1| & Cucurbitaphid-boyellows virus from China: Xinjiangcompletegenome \\
\hline gi|20260786|reflNC..003688.11.. & .Cucurbitaphid-boyellows virus,completegenome".................. \\
\hline$g i|226426425| g b|f J 751927.1|$ & "Citrus exocortiYucatan viroid isolate 9, completegenome" \\
\hline$g i|226426428| g b|F J 751930.1|$ & "Citrus exocortiYucatan viroid isolate 12 , completegenome" \\
\hline gi|226426431|gb|Fj751933.1| & "Citrus exocortiYucatan viroid isolate 15 , completegenome" \\
\hline 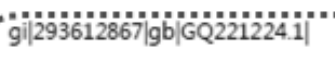 & Cucurbitaphid-boyellows virus isolate CABŸ-jAcompletegenome" \\
\hline gi|295675094|gb|GQ221223.1| & Cucurbitaphid-boyellows virus isolate CABW-FJcompletegenome \\
\hline gi|336444806|gb|HQ439023.1| & Cucurbitaphid-boyellows virus strain CABW-CZcompletegenome \\
\hline gi|388325674|gb|JF939812.1| & Cucurbitaphid-boyellows virus strain Sq/2003/completegenome \\
\hline gi|388325686|gb|JF939813.1| & Cucurbitaphid-boyellows virus strain Sq/2005/completegenome \\
\hline gi|388325696|gb|JF939814.1| & Cucurbitaphid-boyellows virus strain $\$ q / 2004 /$ completegenome \\
\hline gi|392328722|gb|JQ700305.1| & Cucurbitaphid-boyellows virus isolate CABYV-C-completegenome \\
\hline gi|392328729|gb|JQ700306.1|. & Cucurbitaphid-boyellows virus isolate CABYV-R-completegenome \\
\hline gi|392718241|gb|JN606110.1| & Cacao swollen shoot virus isolate C1152-09completegenome \\
\hline gi|41353207|gb|AY513268.1| & "Citrus exocortiviroid, completegenome" \\
\hline gi|440496637|gb|Jx997952.1| & "Garlic virus A isolate WA7, completegenome" \\
\hline$g|540270988| g b|K C 427105.1|$ & Citrus exocortiYucatan viroid isolate CEYVd-WAcompletegenome \\
\hline gi| $564886468|g b| A F 395898.3 \mid$ & "Hibiscuslatent Singaporvirus, completegenome" \\
\hline gi|58119512|gb|AY789137.1| & "Dulcamarmottle virus, completegenome" \\
\hline gi|75905689|gb|AY147260.2| & "SclerotisclerotidebilitaRNA virus, completegenome" \\
\hline gi|79676039|emb|AM109896.1| & "Pepino mosaic virus completegenome, isolate SM.74" \\
\hline$g|86651786| g b|D Q 318792.1|$ & "Citrus exocortiviroid clone $2 / 5$, completegenome" \\
\hline$g i|86651787| g b|D Q 318793.1|$ & "Citrus exocortiviroid clone $5 / 5$, completegenome" \\
\hline gi|9629160|ref|NC_001747.1| & "Potato leafrollvirus, completegenome" \\
\hline
\end{tabular}
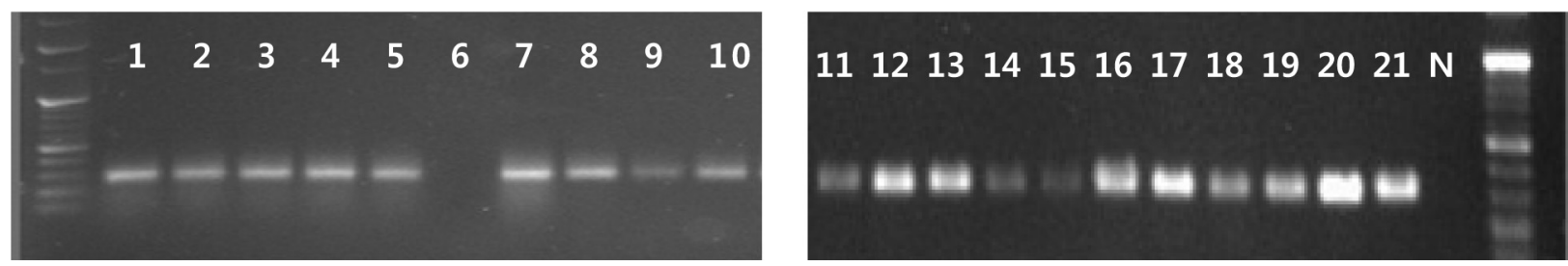

Fig. 4. RT-PCR results of melon using the CABYV specific primers. $\mathrm{N}$, negative control. 
인(Juarez, 2004), 튀니지(Mnari, 2005), 이집트(Omar and Bagdady, 2012), 미국(Lemaire et al., 1993) 및 네팔(Dahal et al., 1997), 레바논(Abou-Jawdah et al., 1997), 중국(Xiang et al., 2008) 등 아시아 지역에서 발생 보고가 있었다. CABYV 에 감염된 멜론은 잎에서는 퇴록반점, 모자이크, 황화 등의 증상을 일으키며, 이병된 과실에서는 불규칙한 네트 형성으 로 상품성이 전혀 없으며 초기 감염주는 과실 형성이 되지 않는 것으로 알려져 있다. 또한 $\mathrm{CABYV}$ 는 호박, 수박, 오이, 상추 등 넓은 기주범위를 가지고 있고, 보독 진딧물은 영속 전염됨에 따라 주변 및 먼 거리 이동으로 인한 확산 가능성

Table 3. Effect of yellowing symptoms on the photosynthetic rate and root activity in the melon plants.

\begin{tabular}{lcc}
\hline Treatment & $\begin{array}{c}\text { Photosynthetic rate } \\
\left(\mu \mathrm{mol} \cdot \mathrm{m}^{-2} \cdot \mathrm{s}^{-1}\right)\end{array}$ & $\begin{array}{c}\text { Root activity } \\
\text { (Absorbance) }\end{array}$ \\
\hline Normal & 12.36 & 0.484 \\
Yellowing symptom & 4.09 & 0.284 \\
Significant & $* * *$ & $* * *$ \\
\hline
\end{tabular}

${ }^{* * *}$ Significant at the $p \leq 0.001$, respectively, by t-test. ${ }^{\mathrm{z}}$ Root activity is calculated by changing in WST-1 formazan absorbance measured after three hours.
이 매우 높을 것으로 판단된다.

멜론 정상엽과 황화엽의 광합성 특성은 Table 3 과 같다. 광합성 능력은 정상엽의 경우 $12.36 \mu \mathrm{mol} \cdot \mathrm{m}^{-2} \cdot \mathrm{s}^{-1}$ 정도이었 고, 황화엽은 $4.09 \mu \mathrm{mol} \cdot \mathrm{m}^{-2} \cdot \mathrm{s}^{-1}$ 로 정상엽과 비교하여 $1 / 3$ 수 준 정도로 낮았다. 이와 같은 결과는 황화증상으로 인하여 잎 내 엽록소가 파괴되어 클로로필 함량이 낮아져서 광합성 능력이 떨어진 결과로 판단되며, 멜론의 황화엽 발생시 광 합성 능력이 낮아졌다는 Takeshita(2004)와 Park 등(2011)의 보고와 유사한 결과이다.

뿌리의 활력은 정상주의 뿌리는 $0.48 \mathrm{mg} \cdot \mathrm{g}^{-1}$ 이었으나 황 화주는 $0.28 \mathrm{mg} \cdot \mathrm{g}^{-1}$ 로 정상주의 뿌리 활력이 황화주보다 1.7 배정도 높은 것을 확인할 수 있었다. Takeshita(2004)는 뿌 리의 양이 적은 품종이 황화증상의 발생에 영향을 미칠 가 능성이 높다고 하였는데, 본 연구의 황화엽 발생주와 정상 주의 뿌리 양은 큰 차이를 보이지 않았다. 그러나 정상주보 다 낮은 뿌리 활력이 황화증상이 나타난 개체의 양수분 흡 수에 영향을 미쳤을 것으로 판단된다.

정상주의 잎과 황화엽 발생개체의 잎을 채취하여 광학 현 미경으로 잎의 세포조직을 검경한 결과는 Fig. 6과 같다. 정 상주의 경우에는 잎 내에 전분이 축적되지 않고 모두 전류된 상태로 보이고, 황화엽증 발생주의 잎은 통도조직 주변을 중

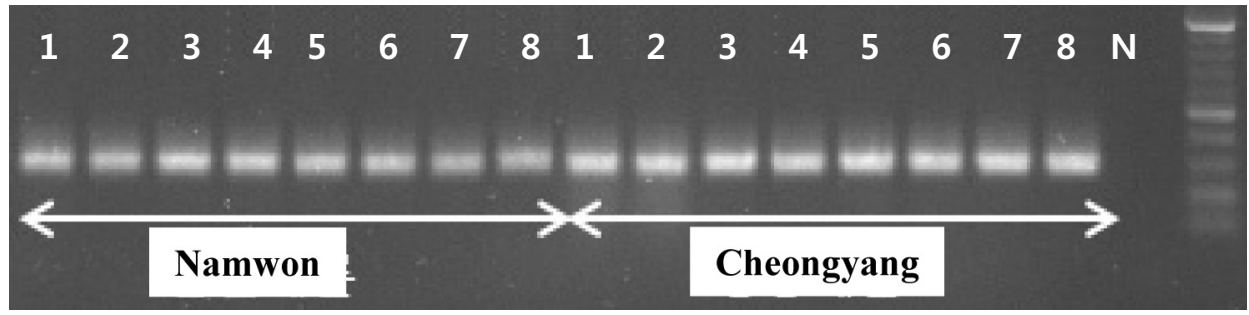

Fig. 5. RT-PCR results of cultivated melons at Namwon and Cheongyang using the CABYV specific primers. N, negative control.
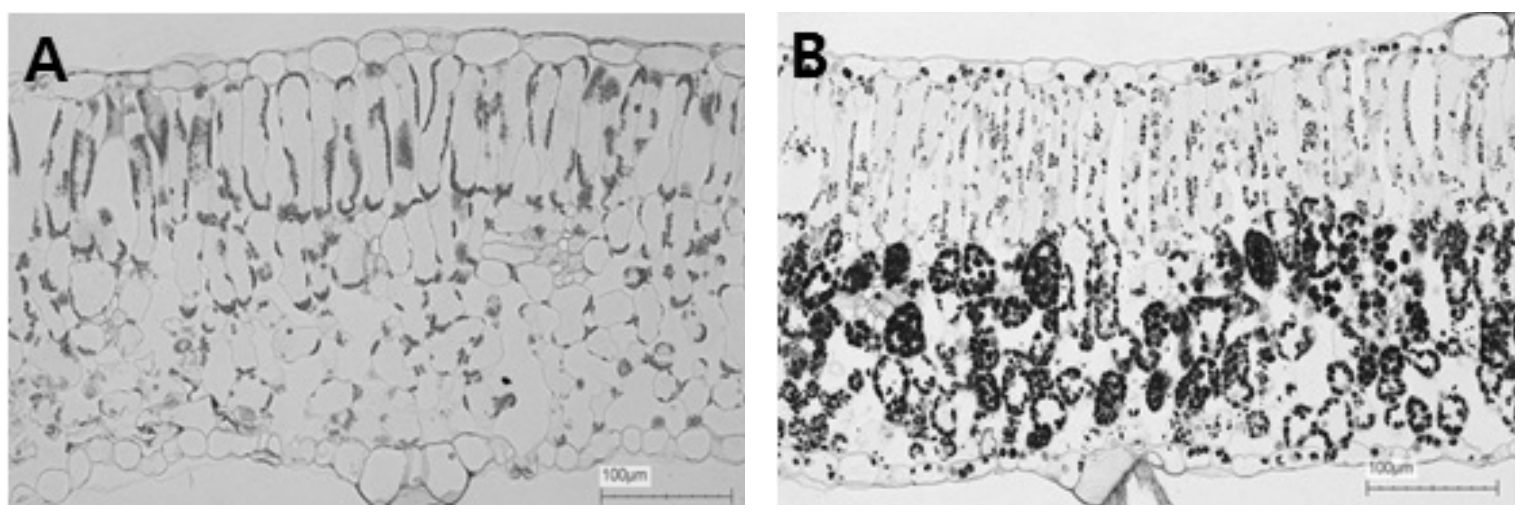

Fig. 6. Cross-sections of leaves from the normal melon plants (A), and from affected plants showing yellowing symptoms (B) collected at the fruit setting stage. 
Table 4. Effect of yellowing symptoms on the mineral concentration in the melon leaves.

\begin{tabular}{lcccccccc}
\hline \multirow{2}{*}{ Treatment } & \multicolumn{7}{c}{ Concentration $\left(\mathrm{mg} \cdot \mathrm{kg}^{-1}\right.$ dry $\left.\mathrm{wt}.\right)$} \\
\cline { 2 - 9 } & $\mathrm{K}$ & $\mathrm{Ca}$ & $\mathrm{Mg}$ & $\mathrm{Na}$ & $\mathrm{Fe}$ & $\mathrm{Cu}$ & $\mathrm{Zn}$ & $\mathrm{Mn}$ \\
\hline Normal & 26,891 & 69,608 & 16,443 & 776 & 258 & 10 & 59 & 79 \\
Yellowing symptom & 17,691 & 35,755 & 8,588 & 357 & 11 & 5 & 29 & 37 \\
Significant & $* *$ & $* * *$ & $* *$ & $* *$ & $* *$ & $* *$ & $* *$ & $* *$ \\
\hline
\end{tabular}

${ }^{* * * * * * *}$ Significant at the $p \leq 0.01$ or 0.001 , respectively, by t-test.

심으로 전분이 많이 축적되어 있는 상태로 전류가 되지 않 은 것으로 사료된다. 즉, 황화증상 개체의 잎은 바이러스의 전이를 막기 위하여 세포의 원형질 연락사(plasmodesmata) 를 막아 광합성 산물이 전류되지 못하고 잎에 축적상태로 남아 있는 것으로 생각된다. 이것은 원형질 연락사 개폐에 관하여 바이러스 감염시 원형질 연락사가 닫힌다는 보고와 같은 맥락으로 판단된다(Epel, 2009; Lee et al., 2011; Lee, 2014).

멜론의 정상주와 황화엽증 발생주의 잎을 채취하여 무기 성분을 분석한 결과는 Table 4 와 같다. 모든 성분에서 황화 엽이 정상엽보다 함량이 낮았고, 특히 마그네슘, 철분, 아연, 나트륨, 망간 성분 함량에 유의차가 큰 것으로 나타났다. 이 와 같이 황화엽의 무기성분 함량이 정상엽보다 낮은 것은 황화증상의 원인이라기보다 황화엽 발생의 결과라고 추정 된다(Takeshita, 2004). 이러한 결과를 토대로 최근에 국내의 멜론 재배지에서 급속하게 발생하고 있는 황화엽 증상은 생 리적인 원인보다는 진딧물에 의한 바이러스 이병에 의한 원 인이 더 큰 것으로 판단된다. 따라서 황화엽 증상 피해 확산 을 줄이기 위해서는 바이러스 매개충인 진딧물을 사전에 방 제하는 것이 좋을 것으로 판단되며 정확한 원인을 구명하기 위해서는 뿌리량, sink-source 크기에 따른 발생 등 다양한 각도에서 연구가 필요하다.

\section{초 록}

최근 멜론 재배지에서 확산되고 있는 멜론 황화엽 증상의 발생 원인을 구명하고자 황화엽 발생개체와 정상 개체간의 생육과 바이러스 이병 여부를 평가하였다. 그 결과 황화증 상을 보이는 멜론 잎에 대해 전자현미경 검경 및 국내 보고 된 박과 감염 8종에 대해 RT-PCR한 결과 바이러스가 진단 되지 않았다. 국내 미보고된 바이러스로 의심되어 차세대유 전체염기서열분석(NGS)를 이용하여 진단한 결과 박과진딧
물바이러스(CABYV)로 판정되어 $\mathrm{CABYV}$ 특이프라이머를 이용하여 RT-PCR 한 결과 모두 CABYV 감염이 확인되었 다. 광합성 능력은 정상엽의 경우 $12.36 \mu \mathrm{mol} \cdot \mathrm{m}^{-2} \cdot \mathrm{s}^{-1}$ 였고, 황 화엽은 $4.09 \mu \mathrm{mol} \cdot \mathrm{m}^{-2} \cdot \mathrm{s}^{-1}$ 로 황화엽이 정상엽의 $1 / 3$ 수준으 로 낮았다. 뿌리의 활력도 정상적인 생육을 보인 멜론에서는 $0.48 \mathrm{mg} \cdot \mathrm{g}^{-1}$ 이었으나 황화증상이 발생한 개체에서는 $0.28 \mathrm{mg} \cdot \mathrm{g}^{-1}$ 로 황화증상 개체의 뿌리 활력이 정상 개체보다 2 배 정도 낮았다. 잎의 무기성분은 모든 성분에서 정상엽이 황화엽보 다 2 배 이상 유의성 있게 높게 나왔고, 특히 철분의 함량은 20 배 정도의 차이를 보였다. 정상 개체와 황화증상 개체의 세포조직을 관찰한 결과, 울타리조직이나 해면조직은 모두 정상적인 모양을 보여 황화증상이 잎의 세포조직에는 영향 을 미치지 않는 것으로 사료되었지만 다만, 황화증상 개체 의 잎은 통도조직의 주변을 중심으로 전분이 많이 축적되 어 있는 것으로 나타나 동화양분의 전류가 되지 않은 것으 로 추정되었다. 따라서 최근에 국내의 멜론재배지에서 급속 하게 발생하고 있는 황화엽 증상은 생리적인 원인보다는 진딧물에 의한 바이러스 이병에 의한 원인이 더 큰 것으로 판단되며 황화엽 증상의 피해와 확산을 줄이기 위해서는 바이러스 매개충인 진딧물을 사전에 방제하는 것이 좋을 것으로 판단된다.

추가 주요어 : 진딧물, 황화엽, 멜론 병, 바이러스병

\section{인용문헌}

Abou-Jawdah, Y., H. Sobh, A. Fayyad, and H. Lecoq. 1997. First report of cucurbit aphid-borne yellows luteovirus in Lebanon. Plant Dis. 81:1331. (Abstr.)

Avgelis, A.D. and N. Katis. 1989. Occurrence of squash mosaic virus in melons in Greece. Plant Pathol. 38:111-113.

Bateson, M.F., J. Henderson, W. Chaleeprom, A.J. Gibbs, and J.L. Dale. 1994. Papaya ringspot potyvirus: isolate variability 
and the origin of PRSV type P (Australia). J. Gen. Virol. 75:3547-3553.

Berridge, M.V., P.M. Herst, and A.S. Tan. 2005. Tetrazolium dyes as tools in cell biology: new insights into their cellular reduction. p. 127-152. In: M.R. EI-Gewely (ed.). Biotechnol. Annu. Rev. Elsevier.

Carver, T., U. Böhme, T.D. Otto, J. Parkhill, and M. Berriman. 2010. BamView: viewing mapped read alignment data in the context of the reference sequence. Bioinformatics 26:676-677.

Chang, S.C. 1973. Compounding of Luft's epon embedding medium for use in electron microscopy with reference to anhydride: Epoxide ratio adjustment. Mikroskopie 29:337-342.

Choi, G.S. 2001. Occurrence of two tobamovirus diseases in cucurbits and control measures in Korea. Plant Pathol. J. 17:243-248

Choi, G.S., J.H. Kim, and J.S. Kim. 2003. Characterization of Melon necrotic spot virus isolated from muskmelon. Plant Pathol. J. 19:123-127.

Dahal, G., H. Lecoq, and S.E. Albrechtsen. 1997. Occurrence of papaya ringspot potyvirus and cucurbit viruses in Nepal. Ann. Appl. Biol. 130:491-502.

Diaz-Pendon, J.A., R. Fernandez-Munoz, M.L. Gomez-Guillamon, and E. Moriones, 2005. Inheritance of resistance to Watermelon mosaic virus in Cucumis melo that impairs virus accumulation, symptom expression, and aphid transmission. Phytopathology 95:840-846.

Dukic, N., B. Krstic, I. Vico, N.I. Katis, C. Papavassiliou, and J. Berenji. 2002. Biological and serological characterization of viruses of summer squash crops in Yugoslavia. J. Agric. Sci. 47:149-160.

Enzie, W.D. 1943. A source of muskmelon mosaic resistance found in the oriental pickling melon, Cucumis melo var. conomon. Proc. J. Am. Soc. Hortic. Sci. 43:195-198.

Epel, B.L. 2009. Plant viruses spread by diffusion on ER-associated movement-protein-rafts through plasmodesmata gated by viral induced host $\beta$-1,3-glucanases. Semin. Cell Dev. Biol. 20: 1074-1081.

Grafton-Cardwell, E.E., T.M. Perring, R.F. Smith, J. Valencia, and C.A. Farrar. 1996. Occurrence of mosaic viruses in melons in the central valley of California. Plant Dis. 80:1092-1097.

Guilley, H., C. Wipf-Scheibel, K. Richards, H. Lecoq, and G. Jonard. 1994. Nucleotide sequence of Cucurbit aphid-borne yellows luteovirus. Virology 202:1012-1017.

Juarez, M. 2004. First report of Cucurbit aphid-borne yellows virus in Spain. Plant Dis. 88:907. (Abstr.)

Kim, J.S., S.H. Lee, H.S. Choi, G.S. Choi, J.D. Cho, and B.N.
Chung. 2008. Survey of viral diseases occurrence on major crops in 2007. Res. Plant Dis. 14:1-9 (ln Korean).

Kim, J.S., S.H. Lee, H.S. Choi, M.K. Kim, H.R. Kwak, J.S. Kim, M. Nam, J.D. Cho, I.S. Cho, and G.S. Choi. 2012. 2007-2011 Characteristics of plant virus infections on crop samples submitted from agricultural places. Res. Plant Dis. 18:277-289.

Langmead, B. and S.L. Salzberg. 2012. Fast gapped-read alignment with Bowtie 2. Nat. Methods 9:357-359.

Lecoq, H. 1999. Epidemiology of Cucurbit aphid-borne yellows virus, p. 243-248. In: H.G. Smith and H. Barker (eds.). The Luteoviridae. CAB International, Wallingford, UK.

Lecoq, H., C. Desbiez, C. Wipf-Scheibel, and M. Girard. 2003. Potential involvement of melon fruit in the long distance dissemination of cucurbit potyviruses. Plant Dis. 87:955-959.

Lecoq, H., and C. Desbiez. 2012. Chapter 3 - Viruses of cucurbit crops in the Mediterranean region: an ever-changing picture, p. 67-126. In: L. Gad and L. Hervé (eds.). Adv. Virus Res. Academic Press.

Lemaire, O., W.D. Gubler, J. Valencia, H. Lecoq, and B.W. Falk. 1993. First report of Cucurbit aphid-borne yellows virus in the United States. Plant Dis. 77:1169. (Abstr.)

Lee, J.H., J.K. Kwon, S.S. Park, Y.C. Huh, C.I. Lim, D.K. Park, and K.D. Ko. 2009. Effect of different rootstocks on wilting occurrence, plant growth, and fruit quality of melon. Kor. J. Hort. Sci. Technol. 27:211-217.

Lee, J.Y., X. Wang, C. Weier, S. Ross, M. Shannon, C. Kirk, Z. Boris, W. Klaas van, Z. Chong, L. Hua, and L. Venkatachalam. 2011. A plasmodesmata-localized protein mediates crosstalk between cell-to-cell communication and innate immunity in Arabidopsis. Plant Cell 23:3353-3373.

Lee, J.Y. 2014. New and old roles of plasmodesmata immunity and parallels to tunneling nanotubes. Plant Science 221-222:13-20.

Li, H., B. Handsaker, A. Wysoker, T. Fennell, J. Ruan, N. Homer, and R. Durbin. 2009. The sequence alignment/map format and SAM tools. Bioinformatics 25:2078-2079.

McKenna, A., M. Hanna, E. Banks, A. Sivachenko, K. Cibulskis, A. Kernytsky, and M.A. DePristo. 2010. The Genome Analysis Toolkit: a Map reduce framework for analyzing next-generation DNA sequencing data. Genome Res. 20:1297-1303.

Mnari, H.M., J. Kummert, S. Russel, K. Ezzaier, A. Zouba, and M.H. Jijakli. 2005. First report of Cucurbit aphid-borne yellows virus in Tunisia causing yellows on five cucurbitaceous species. Plant Dis. 89:776. (Abstr.)

Moon, J.H. 2001. Physiological responses of cucumber to root-zone temperature. PhD. Diss., Seoul National Univ., Seoul, Korea. 
NIAST. 2000. Methods of soil chemical analysis. National Institute of Agricultural Science and Technology, RDA, Suwon, Korea.

Omar, A.F. and N.A. Bagdady. 2012. Cucurbit aphid-borne yellows virus in Egypt. Phytoparasitica 40:177-184.

Papayiannis, L.C., N. Ioannou, I.N. Boubourakas, C.I. Dovas, N.I. Katis, and B.W. Falk. 2005. Incidence of viruses infecting cucurbits in Cyprus. J. Phytopathol. 153:530-535.

Park D.K., S.H. Son, K.R. Do, W.M. Lee, and H.J. Lee. 2011. Effects of leaf chlorosis on the melon fruits and growing. Kor. J. Hort. Sci. Technol. 29:66-67. (Abstr.)

Rajamony, L., T.A. More, V.S. Seshadri, and A. Varma. 1987. Resistance to Cucumber Green Mottle Mosaic Virus (CGMMV) in Muskmelon. Cucurbit Gen. Coop. Rep. 10:58-59. (Abstr.) Ryu, S.H. 2009. List of Plant Diseases in Korea. 800-805.

Takeshita, S. 2004. Melons, p. 375-379. Vegetable gardening encyclopedia. Rural Culture Association Japan.
Tamura, K., G. Stecher, D. Peterson, A. Filipski, and S. Kumar. 2013. MEGA6: molecular evolutionary genetics analysis version 6.0. Mol. Biol. Evol. 30:2725-2729.

Tan, S.H., M. Nishiguchi, M. Murata, and F. Motoyoshi. 2000. The genome structure of kyuri green mottle mosaic tobamovirus and its comparison with that of cucumber green mottle mosaic tobamovirus. Arch. Virol. 145:1067-1079.

Tomassoli L. and M. Meneghini. 2007. First report of cucurbit aphidborne yellows virus in Italy. Plant Pathol. 56:720. (Abstr.) Vucurovic, A., A. Bulajic, I. Ekic, D. Ristic, J. Berenji, and B. Krstic. 2009. Presence and distribution of oilseed pumpkin viruses and molecular detection of Zucchini yellow mosaic virus. Pestic. Fitomed. 24:85-94.

Xiang, H.Y., Q.X. Shang, C.G. Han, D.W. Li, and J.L. Yu. 2008. Complete sequence analysis reveals two distinct poleroviruses infecting cucurbits in China. Arch. Virol. 153:1155-1160. 